\title{
Livestock based integrated farming systems for livelihood improvement of small and marginal farmers
}

\author{
S.A. Kochewad*, L.R. Meena, Devender Kumar, Sanjeev Kumar, L.K. Meena, S.P. Singh, \\ and Khushyal Singh
}

ICAR-Indian Institute of Farming Systems Research, Modipuram-250110, Uttar Pradesh

*Email:sanjiv_kochewad@yahoo.com

\begin{abstract}
Livestock based integrated farming system provides an opportunity of increasing economic yield per unit area per unit time to small and marginal farmers. In this system, waste materials are effectively recycled by linking appropriate components. Thus, minimize the environment pollution. Recycling of product, byproducts and waste material in integrated farming system are the factors responsible for the sustainability of farming system. Due to integration of different livestock components with crops, production of eggs, meat and milk provide nutritional security and income generation round the year to the farmers. Combining crop with livestock enterprises would increase the labour requirement significantly and helps in reducing the problems of under employment to a great extent. IFS provide enough scope to engage family labour round the year. The nutritional security, natural resource management and environment protection are the major concern for sustainable agriculture. Integration of livestock is the way forward to promote proper utilization of available resources and environment protection for economic growth. Integrated farming system diversifies farm production, increase the income, improve nutritional security and promote nutrient recycling.
\end{abstract}

Paper cited: Kochewad, S.A., Meena, L.R., Kumar, D., Kumar, S., Meena, L.K., Singh, S.P. and Singh K. (2017). Livestock based integrated farming systems for livelihood improvement of small and marginal farmers. South Asian J. Food Technol. Environ., 3(1):526-532.

\section{Introduction}

India is having huge diversified livestock resources enriching the life of millions of people of rural India. Livestock resources are the key components in sustainable agriculture. India is having 512.1 millions livestock population. India ranks first in buffalo population (108.7 million), second in cattle (190.9 million) and goat population (135.2 million) and third in sheep population (72 million) in the world $\left(19^{\text {th }}\right.$ Livestock census 2012). Livestock provides livelihood to twothird of rural community and generates employment to about $8.8 \%$ of the population in India (Dash, 2017). The livestock sector contributes 4.11\% GDP (Gross Domestic Production) and $25.6 \%$ of total Agriculture
GDP. India is number one milk producer in the world with 146.3 million tones of milk. Similarly it is producing about 78.5 billions of eggs, and $48.1 \mathrm{~kg}$ of wool. The livestock also contributes to the production of valuable manure, leather and pelts. Livestock based integrated farming system is a traditional practice in rural India among the small and marginal farmers. Diversification of crop based agriculture with dairy, goatery, fishery, poultry, duckery, etc. is necessary for increasing the income of farmers (Ray et al., 2012). Livestock holdings is more equally distributed among farmers compared to land holdings (Birthal and Rao, 2002).The major emphasis in the farming system is productive recycling of farm wastes. Different components of farming system work 
together in integrated farming system resulting in higher total productivity than the sum of their individual production. The output from one enterprise becomes the input of another enterprise, thus improving the resource use efficiency. Due to fragmentation in land holding of farmers, it is necessary to integrate land based enterprises like fishery, poultry, duckery, apiary, field and horticultural crops etc. within the bio-physical and socio-economic condition of the farmers to make farming more profitable and dependable (Behera et al., 2004). Livestock sector provides employment and regular income to the farmers during lean periods through sale of milk. Livestock serve as moving banks and assets which provide economic security to the farmers during hardship. Livestock is source for capital and an insurance against crop production risks, a coping mechanism against livelihood shocks as well as a vital source of dietary protein. Agriculture provides seasonal employment for a period of 56 months in a year and livestock rearing provides employment during lean period. The livestock sector also provides nutritional security (milk, meat and eggs) to the farmers. Livestock provides self esteem to the farmers, when they own elite animals such as pedigreed bulls and high yielding dairy animals. Cow dung and other fodder wastes are decomposed into valuable farm yard manure. Rangnekar (2006) reported that $40-60 \%$ of dung is used as manure and rest as fuel. Farmers also use cow dung as fuel and plastering material. In most of the parts of rural India, still depend upon bullocks for various agricultural operations. The small and marginal farmers depend upon bullocks for ploughing, carting and transport of both inputs and outputs. The bullocks are saving a lot of fuel which is necessary input for using mechanical power operations. Considering the economic importance of draught power, draught animal power is included as one of the 14 sources of renewable energy by (Ramaswamy, 1998) the UN Conference in Nairobi on New and Renewable Sources of Energy. Pack animals like camels, horses, donkeys, ponies, mules, mithun etc. also contribute for transportation of goods in different parts of the country in hilly terrains. Livestock are being used in many places in different crops as biological weed controller.

Table 1: Trend in livestock population (Millions)

\begin{tabular}{|c|c|c|c|c|c|c|}
\hline Species & 1951 & 1982 & 1992 & 2003 & 2007 & 2012 \\
\hline Cattle & 155.3 & 192.5 & 204.6 & 185.2 & 199.1 & 190.9 \\
\hline Buffalo & 43.4 & 69.8 & 84.2 & 97.9 & 105.3 & 108.7 \\
\hline $\begin{array}{l}\text { Total } \\
\text { Bovines }\end{array}$ & 198.7 & 262.4 & 289.0 & 283.1 & 304.4 & 300.0 \\
\hline Sheep & 39.1 & 48.8 & 50.8 & 61.5 & 71.6 & 65.1 \\
\hline Goat & 47.2 & 95.3 & 115.3 & 124.4 & 140.5 & 135.2 \\
\hline $\begin{array}{l}\text { Horses and } \\
\text { ponies }\end{array}$ & 1.5 & 0.9 & 0.8 & 0.8 & 0.6 & 0.6 \\
\hline Camels & 0.6 & 1.1 & 1.0 & 0.6 & 0.5 & 0.4 \\
\hline Pigs & 4.4 & 10.1 & 12.8 & 13.5 & 11.1 & 10.3 \\
\hline Mules & 0.1 & 0.1 & 0.2 & 0.2 & 0.1 & 0.2 \\
\hline Donkeys & 1.3 & 1.0 & 1.0 & 0.7 & 0.4 & 0.3 \\
\hline Yaks & - & 0.1 & 0.1 & 0.1 & 0.1 & 0.1 \\
\hline $\begin{array}{l}\text { Total } \\
\text { livestock }\end{array}$ & 292.8 & 419.6 & 470.9 & 485.0 & 529.7 & 512.1 \\
\hline Poultry & 73.5 & 207.7 & 307.1 & 489.0 & 648.8 & 729.2 \\
\hline
\end{tabular}

(Source: Department of Animal Husbandry, Dairying and Fisheries) 
Livestock based integrated farming systems for livelihood improvement of small and marginal farmers

Table 2: Trend in production of milk, eggs and wool in India

\begin{tabular}{llll}
\hline Year & Milk (Million Tones) & Eggs(Billion Nos) & Wool (Million kgs) \\
\hline $1990-91$ & 53.9 & 21.1 & 41.2 \\
$2000-01$ & 80.6 & 36.6 & 48.4 \\
$2009-10$ & 116.4 & 60.3 & 43.1 \\
$2010-11$ & 121.8 & 63.0 & 43.0 \\
$2011-12$ & 127.9 & 66.5 & 44.7 \\
$2012-13$ & 132.4 & 69.7 & 46.1 \\
$2013-14$ & 137.7 & 74.8 & 47.9 \\
$2014-15$ & 146.3 & 78.5 & 48.1 \\
\hline
\end{tabular}

(Source: Department of Animal Husbandry, Dairying and Fisheries)

\section{Livestock based farming systems} Livestock+Crop based farming system: Livestock + crop farming system is a predominant farming system prevalent in most of the parts of India. Integrating crops with livestock on the same farms helps smallholder farmers to diversify the sources of income and employment generation. Crop and livestock complement one another through mutual benefit. In livestock + crop system, the animal component is often raised on agricultural waste products while the animal is used to cultivate the land and provide manure to be used as fertilizer and fuel (Jayanthi et al., 2000). The animals play important role in enriching the soil gradually and increasing soil organic matter to support the crop. The draft power of animals is used for farm operations, while crop residues provide fodder for livestock and grain provides supplementary feed for productive animals. Animals also provide manure and other types of animal waste. Alam et al., (2000) reported that the manure availability was 12 tonnes from a pair of draught cattle integrated with crop. Cow dung helps in the overall sustainability of the farming system. Dung contains macro and micro nutrients required for improving the soil fertility and crop growth. Cow dung is used for the production of biogas. Biogas is a source of renewable, alternative and sustainable energy (Godi et al., 2013). Per ton manure contains $8 \mathrm{~kg}$ of nitrogen, $4 \mathrm{~kg}$ of phosphorus and $16 \mathrm{~kg}$ of potassium. Application of manure improves the soil fertility and water holding capacity. The cost of weed control is reduced where the livestock graze under plantations. Venkatadri et al., (2008) reported that 98 per cent of the farmers opined that livestock rearing reduces vulnerability in drought years, 97 per cent of the sample respondents indicated that farmers suicides were less in dairy developed areas and commercial agriculture increased suicidal rate in Andhra Pradesh (96.\%). Integrated farming system with six buffaloes generated 904 of man days of employment against 400 man days in crop alone (Pandey and Bhogal, 1980)

Livestock + Crop + Fish based farming system: Livestock + Crop + Fish farming systems can be followed by integrating fish with Livestock +Crop farming system, raise the fish without any additional feed, rearing fish in the fish pond with the help of available dung from livestock. Integrated Livestock + Crop + fish farming can be carried out for increasing returns from a limited land area and reducing risk by diversifying crops (Korikantimath et al., 2008). There should be ample supply of fresh and clean water available throughout the year to maintain water level for fish management purposes. The nutrients content in cow dung will help in growth of phytoplankton and zooplankton in fish pond. The by-products of livestock can be used for aquaculture. Direct application of wastes of livestock is common practice. The by-products of livestock are manure, urine and spilled feed. The adult cattle produce about 4,000-5,000 kg 
dung, 3,500-4,000 liter urine annually. For a pond size of 1 ha of 5-6 adult cattle can provide adequate manure. In addition to $9,000 \mathrm{~kg}$ of milk, about 3,000-4,000 kg fish/ha/year can be produced in this system. This system will save labor for lifting the cow dung. The requirement of green and dry fodder for an adult cattle is 910 and 2-2.2 ton respectively and will be met from crop component. The manure will be used for improving the fertility of soil. Mahajan et al., (2012) reported that inclusion of dairy and poultry components in IFS, the net income have been increased to Rs 37,343/- per year as against Rs 26,511/- from field crops only.

Poultry + Fish based farming system: Poultry+ fish farming system can be integrated to reduce the cost of fertilizers and feeds in fish farming. Poultry can be reared near or over the fish pond and the poultry excreta will directly drop into fish pond and get recycled. In this system poultry is reared under deep litter system. Poultry droppings in the form of litter contains: $3 \%$ nitrogen, $2 \%$ phosphate and $2 \%$ potash. Poultry droppings acts as a good source of fertilizer which helps in producing fish feed i.e. phytoplankton and zooplankton in fish pond. Njoku and Ejiogu (1999) reported that 1000 chicken can be integrated with one hectare fish pond provided the optimal water quality for fish survival and growth and also reported that the excreta load was $3600 \mathrm{~kg} \mathrm{ha}^{-1}$ month $^{-1}$ (dry matter); water $\mathrm{pH} 8.6$; total alkalinity 65.0 $\mathrm{mg} \mathrm{L}^{-1}$; dissolved oxygen $8.0 \mathrm{mg} \mathrm{L}^{-1}$; biochemical oxygen demand (BOD) $2.0 \mathrm{mg} \mathrm{L}^{-1}$; ammonia $0.02 \mathrm{mg} \mathrm{L}^{-1}$ and total phosphates 10.0 $\mathrm{mg} \mathrm{L}^{-1}$. Fish yield range from 4000-5000 $\mathrm{Kg} / \mathrm{ha} / \mathrm{yr}$. Poultry-fish integration increases the resource use efficiency and proper utilization of space and eco-friendly. Gangwar et al., (2013) reported that the integrated poultry-fish farming provided additional income of Rs. 4000-5000 per annum and generated 45-50 man days of employment. Sahoo and Singh, (2015) reported that, the fish-poultry farming system could generate maximum profit of Rs. 33664.06 per

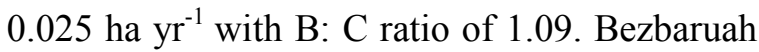
(2012) reported that integrating, Poultry + Fish

+ Horticulture farmer earned Rs. 40,000 from poultry, Rs. 25,000 from fish and Rs. 6000 from vegetable growing on the bunds of pond. Kalita et al., (2016) reported that Fish+Poultry integration produced 4500 to $5000 \mathrm{~kg}$ fish, 70,000 eggs and $1000 \mathrm{~kg}$ (live weight) of chicken meat from 1.0 ha fish pond annually without any supplementary feed.

\section{Livestock +Crop+ Backyard poultry}

Backyard poultry plays a significant role in rural people's life for generating income and nutritional security of the family (Mandal et al., 2006). Integration of livestock + crop farming with backyard poultry farming will improve the nutritional security as well as increase the income of farmers. Backyard livestock comprising of sheep, goats, pigs and poultry provide emergency sources of income for family as reported by Devendra and Pezo (2002). Bird scavenges on the undigested grains in dung as well as the threshing wastes in the fields. Backyard poultry also predates the insect and pests which are responsible for incidence of diseases in the crops. Separate inputs are not required for additional feeding of the birds. Eggs and chicken are good source of protein available to the farm family as well as provide income on regular basis. Nirmala et al., (2012) reported that improved backyard poultry as a scientific intervention improved household income. Backyard poultry as a subsidiary occupation substituted farm income as a secondary income source. Majority of the women (51\%) earned 6$10 \%$ of maximum household income from backyard poultry, with high income (11-20\%) from $28 \%$ of women and only 7 women members have earned 21-30\% income from poultry.

Small ruminant + Crop + Horticulture based farming system: Small ruminants play a vital role in the economy of small, marginal and 
landless farmers in the country. Integration of these enterprises can increase the total productivity; maintain ecological balance and economic sustainability. Small ruminants based integrated farming system will also provide income to the farmers, helps in improving the soil fertility, weeds will be utilized as fodder by goat and incidences of diseases in crop will be minimized. Senthilvel et al., (1998) reported that the integration of Crop+Fruit trees+ Goat in dry land resulted in a considerable increase in income of small and marginal farmers of Southern Zone of Tamil Nadu. Small ruminants can directly graze fodder tree/shrubs. Thus, this system will save labors. The grazing periods for small ruminants in this system is of 1-2 weeks, followed by recuperation periods for 3-6 weeks. Under arid condition the recuperation period may need to be longer. Horticulture plantation will be place for movement of small ruminants under this system and boundary plantation will provide fodder to the small ruminants during lean period. Horticulture trees will provide high quality leaf fodder for small ruminants and fruits for income generation. Ramana et al.,(2011) reported that, the performance of Nellore Zodpi ram lambs under hortipastoral systems, that lambs with complementary grazing on established pasture supplemented with L. leucocephala foliage gained significantly $(\mathrm{P}<$ 0.01 ) higher live weight and higher average daily gain than .

Small ruminant + Silvi pastoral based farming system: In this system improved pasture species or mixture of grasses are grown along with perennial trees on same piece of land. It involves grazing of animals and looping of tree leaves as fodder for animals. This system solves the problem of green fodder and reduces the cost of concentrated feed to animals during lean period. Fodder trees such as Leucaena latisiliqua, Bauhinia variegata, Albizzia labbek, Albizzia amara, Moringa olerifera, Sesbania sesban, S. grandiflora, Hardwickia binata are used in different regions of the country for silvi pastoral systems. Ramana et al., (2000) reported that the lambs and kids grazed on silvipasture gained in their body weight at the rate of 54.8 and $36.8 \mathrm{~g}$ (head/day), whereas on natural grassland showed 41.2 and $26.4 \mathrm{~g}$ weight gain (head/day) respectively in the total period of 478 grazing days. The animals were able to gain body weight continuously on both the pasture without any supplementation of concentrate feed. Integrated farming system, sorghum + cowpea, Leucaena leucocephala + Cenchrus ciliaris, Acacia senegal + Cenchrus ciliaris with integration of goat generated an additional employment of 113 mandays $\mathrm{ha}^{-1}$ annually in dry lands (Ramasamy et al., 2007). Due to grazing of animals the fertility builds up with dung and urine adds valuable nutrients to the soil. The movements of animals during grazing the leaves and shrubs are disturbed that harbor insect and pest; because of this the incidence of diseases will be low. Trees provide timber and fodder for animals during lean period.

\section{Conclusion}

Livestock based integrated farming system provides an opportunity of increasing economic yield per unit area per unit time in small and marginal farmers. In this system waste materials are effectively recycled by linking appropriate components. Thus minimize the environment pollution. Recycling of product, byproducts and waste material in integrated farming system are the factors responsible for the sustainability of farming system. Due to integration of different livestock components with crops, production of eggs, meat and milk provide nutritional security and income generation round the year to the farmers. Combining crop with livestock enterprises would increase the labour requirement significantly and helps in reducing the problems of under employment to a great extent. IFS provide enough scope to employ family labour round the year. The nutritional security, natural resource management and 
environment protection are the major concern for sustainable agriculture. Integration of livestock is the way forward to promote proper utilization of available resources and environment protection for economic growth. Integrated farming system diversifies farm production, increase the income, improve nutritional security and promote nutrient recycling.

\section{References}

1. Alam, M.R., Sarker, R.I., Hossain M.D. and Islam, M.S. (2000). Contribution of livestock to small farms in Bangladesh. Asian Australasian Journal of Animal Science., 13:339-342.

2. Behera, U. K., Jha, K. P. and Mahapatra, I. C. (2004). Integrated management of available resources of the small and marginal farmers for generation of income and employment in eastern India. Crop Research, 27: 83-89.

3. Bezbaruah, P. (2012). Ensuring livelihood through integrated farming system. In: Munda, G.C., Ngachan, S.V., Das, A., Mohapatra, K.P., Choudhury, B.U., Ramkrushna, G.I., Tripathi, A.K., Azad Thakur, N.S., Malngiang, S. and Chowdhury, S. (2012). Book of Extended Summaries. The National Seminar on Livelihood Options for Small and Marginal Farmers in Fragile Ecosystems. ICAR Research Complex for NEH Region, Umiam- 793 103, Meghalaya.

4. Birthal, P.S. and Parthasarathy Rao, P. (2002). Economic contributions of the livestock sub-sector in India. In: Birthal, P.S. and Parthasarathy Rao, P. (Eds.), Technology Options for Sustainable Livestock Production in India, Proceedings of ICAR-ICRISAT Collaborative Workshop on Documentation, Adoption, and Impacts of Livestock Technologies in Mixed Crop-
Livestock Farming Systems in India, ICRISAT, Patancheru, India, pp. 12-19

5. Dash, S. (2017). Contribution of Livestock Sector to Indian Economy. Indian Journal of Research, 6:890-891.

6. Department of Animal Husbandry, Dairying and Fisheries. Government of India, 19th Livestock Census; 2012.

7. Devendra, C. and Pezo, D. (2002). Improvement of crop animal systems in rainfed agriculture to food security and livelihoods in south East Asia. In; Proceedings International symposium on sustaining food security and managing natural resources in South East Asia, Einselen Foundation, Ulm, Germany and Chiang Mai 1 University, Chiang Mai. pp. 129-131.

8. Gangwar, L.S., Saran, S. and Kumar, S. (2013). Integrated Poultry-Fish Farming Systems for Sustainable Rural Livelihood Security in Kumaon Hills of Uttarakhand. Agricultural Economics Research Review, 26:181-188.

9. Godi, N.Y., Zhengwuvi, L.B., Abdulkadir, S. and Kamtu, P. (2013). Effect of cow dung variety on biogas production. Journal of Mechanical Engineering Research, 5:1-4

10. Jayanthi, C., Rangasamy, A. and Chinnusamy, C. (2000). Water budgeting for components in lowland integrated farming systems. Agricultural Journal, 87:411-416.

11. Kalita, G., Ahmed, FA., Bora, L., Buragohain, R., Sarma, K Rahman, S., Kalita, A and Nongthombam, J. (2016). Integrated Farming Systems for North Eastern Hilly Region. CAU Farm Magazine 6:4-11.

12. Korikantimath, V.S. and Manjunath, B.L. (2008). Integrated farming systems for sustainability in agricultural production. Proceedings of national symposium on new paradigms in agronomic research. 
Indian Society of agronomy. Navsari Agriculture University. Gujarat, 279- 281.

13. Mahajan, M.S., Kolage, A.K., Desale, S.B. and Nerkar, S.C. (2012). Economics of Integrated Farming System Modules in Dhule, Maharashtra. In: Munda, G.C., Ngachan, S.V., Das, A., Mohapatra, K. P., Choudhury, B.U., Ramkrushna, G.I., Tripathi, A.K., Azad Thakur, N.S., Malngiang, S. and Chowdhury, S. (2012). Book of Extended Summaries. The National Seminar on Livelihood Options for Small and Marginal Farmers in Fragile Ecosystems. ICAR Research Complex for NEH Region, Umiam- 793 103, Meghalaya.

14. Mandal, M.K., Khandekar, N. and Khandekar, P. (2006). Backyard poultry farming in Bareilly district of Uttar Pradesh, India: an analysis. Livestock Research for Rural Development, 18 (7), http:// www.lrrd.org/lrrd18/7/mand18101.htm.

15. Nirmala, G., Ramana, D.B.V. and Venkateswarlu, B. (2012). Women and Scientific Livestock Management: Improving Capabilities through Participatory Action Research in Semi Arid Areas of South India. APCBEE Procedia 4:152- 157.

16. Njoku, D. C. and Ejiogu, C. O. (1999). Onfarm trials of an integrated fish-cum-poultry farming system using indigenous chickens. Aquaculture Research, 30: 399-408.

17. Pandey, R.N. and T.S. Bhogal (1980). Prospects of increasing income and employment on mixed farms. Indian Journal of Agricultural. Economics, 35: 144-151.

18. Ramana, D.B.V., Reddy, N.N., Rao, G. R. (2011). Hortipastoral systems for ram lamb production in rain fed areas. Annals of Biological Research, 2:150.

19. Ramana, D.B.V., Rai, P., Solanki, K.R. and Singh, U.P. (2000). Comparative performance of lambs and kids under silvopastoral system. In: Proc.III Biennial
ANA conference-2000, Hissar, pp 4748.

20. Ramasamy, C., Natarajan, S., Jayanthi, C. and Sureshkumar, D. (2007). Intensive integrated farming system to boost income of farmers. In: Proceedings of 32nd IAUA vice chancellors annual convention on Diversification in Indian Agriculture, Birsa Agricultural University, December 20 - 21. pp. 28-47.

21. Ramaswamy, N.S. (1998). Draught animal welfare. Applied Animal Behaviour Science., 59: $73-84$

22. Rangnekar, D.V. (2006). Livestock in the livelihoods of the underprivileged communities in India: A review. Nairobi, Kenya: ILRI

23. Ray, M., Samanta, B., Haldar, P., Chatterjee, S. and Khan, D.K. (2012). Agriculture Practices and Its Association with Livestock in Hilly Areas of West Bengal. Indian Journal of Hill Farming, 25:53-57

24. Sahoo, U.K. and Singh, S.L. (2015). Integrated Fish-Pig and Fish-Poultry Farming in East Kalcho, Saiha District of Mizoram, North-East India: An Economic Analysis. International Journal of Agriculture and Forestry, 5: 281-286.

25. Senthilvel, T., Latha, K.R. and Gopalasamy, N. (1998). Farming system approach for sustainable yield and income under rainfed vertisols. Madras Agriculture Journal, 55: 65-67

26. Venkatadri, S., Swaroopa Rani, K. and Raghunadha Reddy, G. (2008). A study on improvement in rural livelihoods through dairy farming. Centre for Self Employment and Rural Enterprises. National Institute of Rural Development, Rajendranagar, Hyderabad - $500 \quad 030$. 